\title{
Kebebasan Beragama di Indonesia (Studi Jemaat Ahmadiyah dalam Perspektif Majelis Ulama Indonesia dan Komisi Nasional Hak Asasi Manusia)
}

\author{
M. Anwar Nawawi \\ Sekolah Tinggi Agama Islam Tulang Bawang \\ E-mail: kiyaianwar1961@gmail.com
}

\begin{abstract}
This paper examines the meaning of religious freedom in Indonesia, the perspective of the Indonesian Ulema Council and the Indonesian National Commission especially in the context of Ahmadiyah. The essence of religion is freedom of religion. Therefore the state should protect the public interest, by guaranteeing the freedom of religion. But what happens in Indonesia as a nation state nempaknya will have difficulty to really fair to the minority. And in Indonesia Islam that becomes the majority often apply this way. This is as it is done with the flow of beliefs, or even against the Islamic groups themselves who call the Ahmadiyya school. Here there is a debate about the meaning of religious freedom between MUI and Komnas HAM. The focus of this paper is how is religious freedom in Indonesia in the perspective of MUI and Komnas HAM in the context of Ahmadiyya Jamaat.
\end{abstract}

Key Words: Religious Freedom, Ahmadiyah, MUI and Komnas HAM.

\section{Abstrak}

Tulisan ini mengkaji tentang makna kebebasan beragama di Indonesia, perspektif Majelis Ulama Indonesia dam Komisi Nasional Indonesia khususnya dalam konteks Ahmadiyah. Esensi dalam beragama, adalah kebebasan dalam beragama. Karena itu negara hendaknya melindungi kepentingan umum, dengan memberikan jaminan kebebasan beragama. Namun yang terjadi di Indonesia sebagai negara kebangsaan nempaknya akan mengalami kesulitan untuk benar- 
benar berlaku adil terhadap kaum minoritas. Dan di Indonesia Islam yang menjadi kaum mayoritas sering berlaku demikian. Hal ini seperti yang dilakukan terhadap aliran kepercayaan, atau bahkan terhadap kelompok Islam sendiri yang menamakan aliran ahmadiyah. Disini terdapat berdebatan makna tentang kebebasan beragama antara MUI dan Komnas HAM. Tujuan kajian tulisan ini adalah bagaimanakah kebebasan beragama di Indonesia dalam perspektif MUI dan Komnas HAM dalam konteks Jamaat Ahmadiyah.

Kata Kunci: Kebebasan Beragama, Ahmadiyah, MUI dan Komnas HAM

\section{A. Pendahuluan}

\section{Latar Belakang Masalah}

Salah satu ajaran Islam yang dengan sempurna menampilkan nilai-nilai universalnya adalah lima buah jaminan dasar yang diberikan Islam kepada warga masyarakat baik secara perorangan maupun kelompok. Satu dari kelima jaminan dasar itu adalah kebebasan berkeyakinan (beragama). ${ }^{1}$ Diantara nilai-nilai kemanusiaan yang juga sangat diperhatikan oleh Islam adalah masalah kebebasan. Kebebasan disini meliputi kebebasan beragama, kebebasan berfikir, kebebeasan berpolitik, kebebasan bertempat tinggal dan segala bentuk kebebasan yang hakiki dalam kebenaran. ${ }^{2}$ Hal ini penting untuk ditegaskan kembali, mengingat dalam sejarah agama-agama dunia, tercatat pembunuhan dan penyingkiran terhadap para pemikir kritis hampir selalu terjadi diberbagai belahan bumi dan setiap zaman. Suatu pemikiran kritis selalu dianggap sebagai kafir, menghina Nabi, menghina Tuhan, melecehkan kaum beragama dan lain sebagainya.

1 Ali Syafie, Konsep-Konsep Istihsan, Istislah dan Maslahah alAmmah, dalam Budy Munawar Rochman (Ed.), Kontekstualisasi Doktrin dalam Syari'ah, (Jakarta: Paramadina, 1995), hlm. 366.

${ }^{2}$ Yusuf Qardlowi, Sistem Masyarakat dalam al-Qur'an dan Sunnah, trj. Abdus Salam Masykur, (Solo: Citra Islami Press, 1997), hlm. 128. 
Kebebasan beragama yang menjadi bagian terpenting dalam kehidupan manusia sudah selayaknya ditempatkan di atas Negara. Karena agama akan kehilangan nilai pokoknya jika hanya dimanfaatkan oleh kepentingan politik sesaat. Di Indonesia, kebebasan beragama aturannya belum sepenuhnya mencakup semua kepentingan kebebasan seluruh agama dan kepercayaan. Pasal 29 UUD 1945 yang menjadi acuan dasar sekaligus jaminan aliran kepercayaan ini mengalami hambatan. Karena beda penafsiran dalam hal arti kepercayaan tersebut. Ada yang mengartikan kepercayaannya tersebut berarti agama. ${ }^{3}$ Dan ada pula yang menganggap kepercayaan tersebut adalah aliran kepercayaan.

Dan salah satu esensi dalam beragama, adalah kebebasan dalam beragama. Karena itu negara hendaknya melindungi kepentingan umum, dengan memberikan jaminan kebebasan beragama. Dalam hal ini Islam menempatkan aspek keadilan pada posisi yang amat tinggi dalam sistem peerundang-undangannya. Disinilah letak pemimpin harus bertanggung-jawab penuh terhadap kelompok menoritas.

Namun yang terjadi di Indonesia sebagai negara kebangsaan nempaknya akan mengalami kesulitan untuk benar-benar berlaku adil terhadap kaum minoritas. Dan di Indonesia Islam yang menjadi kaum mayoritas sering berlaku demikian. Hal ini seperti yang dilakukan terhadap aliran kepercayaan, atau bahkan terhadap kelompok Islam sendiri yang menamakan aliran ahmadiyah. Sehingga masih sangat jauh dari harapan akan terciptanya kebebasan beragama seperti yang telah diajarkan dalam agama Islam sendiri. Dan nampaknya, politisasi agama mayoritas lebih melekat dan jauh dari nilai agama Islam sendiri yang menajarkan bahwa Islam adalah rahmat bagi seluruh alam.

${ }^{3}$ Kuntowijoyo, Identitas Politik Islam, (Bandung: Mizan, 1997), hlm. 169. Lihat juga, Hamka Kaq, Islam Rahmah Untuk Bangsa, (Jakarta: RMBOOKS, 2009), hlm. 223.

Fikri, Vol. 3, No. 1, Juni 2018 
Kelompok Ahmadiyah mendapatkan pandangan dari berbagai pihak, terutama Islam, karena pemahaman dan interpretasi yang berbeda terhadap al-Qur'an dan Hadits Nabi SAW. Tidak terkecuali adalah peristiwa vonis sesat dan kafir yang ditunjukan kepada Mirz Ghulam Ahmad dan Ahmadiyah. Pemikiran Mirza Ghulam Ahmad tentang kenabian, wahyu al-Mahdi, al-Masih, konsep khilafat dan Jihad yang kemudian menjadi doktrin Ahmadiyah dianggap keluar dari jalur Islam sehingga membuat keyakinan kelompok lain terusik termasuk kelompok keagamaan Islam di Indonesia. ${ }^{4}$

Lebih dari itu, penyerangan terhadap aliran Ahmadiyah dengan kekerasan fisik juga terjadi, kekerasan secara fisik dialami warga Ahmadiyah yang mengakibatkan ratusan Warga Ahmadiya harus mengungsi. ${ }^{5}$ Selain itu juga terdapat spikologis, karena berbagai amcaman datang kepada warga Ahmadiyah karena dianggap menyesatkan masyarakat. Warga Ahmadiyah pun tidak merasa aman dan hak-haknya untuk hidup aman, terhalangi dan sudah tidak ada.

Secara teoritis, salah satu syarat bagi suatu negara hukum adalah adanya jaminan atas hak-hak asasi manusia (HAM). ${ }^{6}$ Perlindungan HAM merupakan amanah konstitusi sekaligus sebuah keniscayaan dalam perlindungan dan pemenuhannya. $^{7}$ Bagaimana dengan aliran Ahmadiyah, keberlangsungan hidupnya, sebagaimana diketahui Indonesi

${ }^{4}$ Iskandar Zulkarnain, Gerakan Ahmadiyah di Indonesia, (Jakarta: LKis, 2005), hlm. vi.

5 "Ahmadiyah dilarang di Cianjur" Majalah Tempo, (Edisi 3-9 Oktobeer 2005), hlm. 20.

${ }^{6}$ Habib Shulton Asnawi, "Dasar Hukum Hakim Mahkamah Konstitusi Dalam Memutuskan Perkara No.46/PUUVIII/2010 Tentang Status Hukum Anak Di Luar Nikah (Perspektif Hukum Islam Dan Hak Asasi Manusia)," FIKRI : Jurnal Kajian Agama, Sosial Dan Budaya 1, no. 1 (3 Maret 2016): 45-78, http://journal.iaimnumetrolampung.ac.id/index.php/jf/article/view/7.

7 Habib Shulton Asnawi, "Politik Hukum Putusan MK Nomor 36/PUU-X/2012 dalam Upaya Mengembalikan Kedaulatan Negara dan Perlindungan HAM," Jurnal Konstitusi 13, no. 2 (27 Agustus 2016): 302, http://ejournal.mahkamahkonstitusi.go.id/index.php/jk/article/view/337. 
bukanlah negara Islam, namun negara yang Bhineka Tunggal Ika, dengan berbagai macam agama, aliran, suku, ras dan budaya. Menurut Musdah Mulia, beliau mengatakan bahwa, perilaku diskriminasi itu muncul akibat berbagai factor, baik structural maupun cultural. Pada tataran cultural, masalah ini muncul akibat tafsir agama yang tidak akomodatif, terhadap nilai-nilai kemanusiaan, mengabaikan prinsip pluralisme, dan cenderung ekslusif. Sementara factor stuktural antar srtuktural antara lain berwujud perraturan perundang-undangan yang diskriminatif dan lemahnya upaya-upaya penegakan hukum (law inforcement) oleh penguasa. ${ }^{8}$

Menurut J.C.T. Somorangkir dalam bukunya "Hukun dan Konstitusi Indonesia" menuliskan bahwa negara hukum menurut Undang-undang Dasar 1945 adalah negara dalam arti luas yang mensejaterakan rakyat dan keadilan social berdasarkan Pancasila. Setiap orang mempunyai kewajibankewajiban terhadap masyarakat karena hanya di situ saja mungkin diperoleh kemajuan kebebasan dan sempurna dari diri pribadi. ${ }^{9}$

Peristiwa tragis yang dialami umat Ahmadiyah sampai sekarang kian mebuktikan masih minusnya rasa saling menghargai perbedaan dan keberagamaan di antara umat Islam sendiri. Indonesi perlu duduk bersama untuk membangun "doalog wacana" mapun "dialoh kehidupan" dalam bingkai spiritualitas dan kemanusiaan, dan berharap tegaknya hukum di Indonesia. Dalam al-Qur'an sendiri disebutkan sejumlah ayat yang mengandung petunjuk dan

${ }^{8}$ Disampaikan oleh: Siti Musdah Mulia, disampaiakan pada seminar sehari dengan tema, "Membangun Persatuan Ditengah Melemahnya Perlindungan Negara terhadap Kebebabasan Beragama di Indonesia. Diselenggarakan oleh dialog center program Paca Sarjana UIN Sunan Kalijaga Yogyakarta:. 24 Maret 2008. Siti Musdah Mulia, Lahir di Bone, Sulawesi Selatan, 3 Maret 1959. Peremuan pertama sebagai Doktor Terbaik IAIN Syahid Jakarta (1997) dengan desertasi: Negara Islam: Pemikiran Husein Haikal. Perempun pertama yang dikukuhkan LIPI sebagai APU (Ahli Peneliti Utama) dilingkungan Departemen Agama (1999)

9 J.C.T. Somorangkir, Hukum dan Konstitusi Indonesia, (Jakarta: PT. Gunung Agung, 1983), hlm. 38. 
pedoman bagi manusia dalam hidup bermasyarakat dan bernegara. Diantara ayat-ayat tersebut mengajarkan tentang kedudukan manusia dibumi dan prinsip-prinsip musyawarah atau konsultasi, ketaatan kepada pemimpin, keadilan persamaan dan kebebasan beragama. ${ }^{10}$ Ada sejumlah hak yang dilanggar atas kejadian-kejadian yang dialami warga Ahmadiyah di dalam UU HAM disebutkan bahwa setiap orang bebas memeluk agama dan kepercayaan, $^{11}$ selain itu di dalam UU HAM juga meneyebutkan bahwa negara menjamin kemerdekaan setiap orang memeluk agamanya masing-masing dan beribadat menurut agama dan kepercayaannya, ${ }^{12}$ selanjutnya tentang hak setiap orang untuk berkumpul, berpendapat dan berserikat untuk maksud damai. ${ }^{13}$

Deklarasi Universal Hak Asasi Manusia (DUHAM) juga menyebutkan beberapa pasal yang menyatakan tentang hak setiap orang atas kebebasan berfikir, berkeyakinan dan beragama, termasuk kebebasan menjalankan dan kepercayaannya. ${ }^{14}$ Maka sudah menjadi rahasia umum, bahwa Indonesia adalah salah satu negara yang memiliki catatan buruk dalam konteks penegakan HAM. Dalam tulisan ini penyusun mengambil kasus Ahmadiyah, dimana terjadi perbedaan penafsiran atau pemahaman yang berbeda antara MUI dan Komisi Nasional HAM. Pandangan kedua lembaga di atas saling bertolak belakang walaupun kedua lembaga ini sama-sama mempunyai tujuan yang sama, yaitu menciptakan masyarakat yang lebih baik. Oleh karena itu, fokus kajian tulisan ini adalah bagaimanakah kebebasan

10 Munawir Sadzali, Islam dan Tata Negara, Ajaran Sejarah dan Pemikiran, (Jakarta: UI Press, 1995), hlm. 4-5.

${ }^{11}$ Lihat Pasal 22 (1) UU. No. 39 tahun 1999.

${ }^{12}$ Lihat Pasal 22 (2) UU. No. 39 tahun 1999.

${ }^{13}$ Lihat Pasal 24 (1) UU. No. 39 tahun 1999.

14 Habib Shulton Asnawi, "Membongkar Paradigma Positivisme Hukum dalam Pemberantasan Korupsi di Indonesia: Pemenuhan Hak Asasi Manusia dalam Negara Hukum," SUPREMASI HUKUM: Jurnal Ilmu Hukum, 2013 , http://www.aifisdigilib.org/uploads/1/3/4/6/13465004/02._ham_islam_dan_barat_habib_shult on_asnawi.pdf. 
beragama di Indonesia dalam perspektif Majelis Ulama Indonesia dan Komisi Nasional Hak Asasi Manusia dalam konteks Jamaat Ahmadiyah?

\section{B. Fakta Kebebasan Beragama di Indonesia}

Wacana kebebasan beragama di Indonesia sesungguhnya sudah berkembang sejak bangsa ini akan diproklamirkan tahun 1945 silam, bahkan jauh sebelum itu. Melalui Badan Penyelidik Usaha-usaha Persiapan Kemerdakan Indonesia (BPUPKI), wacana ini hangat diperdebatkan founding father khususnya dalam perumusan pasal 29 UUD 1945. Setua persoalan ini muncul, masalah kebebasan beragama memang tidak pernah tuntas diperdebatkan hingga sekarang. ${ }^{15}$

Semula, rancangan awal pasal 29 dalam UUD 1945 BPUPKI berbunyi: "Negara berdasar atas ketuhanan dengan kewajiban menjalankan syariat Islam bagi pemelukpemeluknya". Lantas diubah lewat keputusan rapat PPKI, 18 Agustus 1945 menjadi "Negara berdasar atas Ketuhanan Yang Maha Esa "Rumusan ini menghilangkan tujuh kata (dengan kewajiban menjalankan syari'at Islam bagi pemelukpemeluknya), yang justru dipandang prinsipil bagi kalangan nasionalis-Islam. Rumusan inilah yang dipakai dalam konstitusi Indonesia hingga sekarang dan tidak mengalami parubahan meski telah empat kali mengalami amandemen:1999, 2000, 2001, dan 2002.

Namun bukan berarti tidak ada usaha serius dari sebagian kalangan Islam untuk mengubah prinsip dasar pasal tersebut. Rekaman perdebatan di sidang-sidang MPR era Reformasi membuktikan dengan jelas dinamika usaha-usaha tersebut. Rapat-rapat PAH I BP MPR tahun 2000 mencatat ada

${ }^{15}$ Siti Musdah Mulia, Potret Kebebasan dan Berkeyakinan di Era Revormasi, Disajikan pada Lokarya Komnas HAM "Penegakan HAM dalam 10 Tahun Revormasi, di Hotel Borobudur Jakarta, 8-11 Juli 2008.

Fikri, Vol. 3, No. 1, Juni 2018 
tiga opsi usulan fraksi-fraksi MPR berkaitan dengan pasal 29 tadi. Pertama. Mempertahankan rumusan pasal 29 sebgaimana adanya tanpa perubahan apapun; Kedua, mengubah ayat 1 pasal 29 dengan, memasukkan "tujuh kata" dalam Piagam Jakarta ke dalamnya seperti rumusan hasil sidang BPUPKI 1945; dan Ketiga, berusaha mengambil jalan tengah dari kedua usulan tersebut, yakni dengan menambahkan satun ayat lagi dari pasal 29 tersebut dangan redaksi yang beragam, di antaranya: "Penyelangara Negara tidak boleh bertentangan dengan nilainilai, norma-norma, dan hukum agama (diusulkan oleh Partai Golkar) "Negara melarang penyebaran faham-faham yang bertentangan dengan Ketuhanan Yang Maha Esa" (diusulkan oleh PPP); dan "Tiap pemeluk agama diwajibkan melaksanakan ajaran agamanya masing-masing" (diusulkan oleh partai Reformasi). ${ }^{16}$

Menarik pula dicatat disini bahwa perdebatan di MPR tentang pasal 29 itu mencakup juga soal pengertian kepercayaan. Sejumlah fraksi di MPR seperti fraksi Partai Demokrasi Indonesia, fraksi Bulan Bintang mengusulkan untuk menghapuskan kata-kata "kepercayaan itu" dari rumusan yang ada karena dianggap membingungkan. Hasil perdebatan panjang di MPR untuk amandemen UUD 1945 menyimpulkan, pasal 29 akhirnya diputuskan untuk tetap kembali pada rumusan semula seperti ditetepkan dalam sidang PPKI. ${ }^{17}$

Sebagai negara pancasila, Indonesia kemudian pada perkembangannya membuat peraturan perundang-undangan tentang kebebasan beragama. Hal ini dimulai sejak pembentukan negara Indonesia yang ditandai dengan azas Ketuhanan Yang Maha Esa pada sila pertama dan dilanjutkan

${ }^{16}$ Siti Musdah Mulia, Potret Kebebasan dan Berkeyakinan di Era Revormasi, hlm. 2.

${ }^{17}$ Sekretariat Jendral, MPR RI, Risalah Rapat-rapat Panitia Ad Hac BP MPR, Buku Kedua Jilid 3C Jakarta, hlm. 564-547. 
pembentukan Undang-undang Dasar 1945. Selanjutnya dalam sila "Kemanusiaan yang adil dan beradab" sejatinya salah satu manifestasi dari sila pertama. Karena Ketuhana Yang Maha Esa dalam manifestasi sosialnya adalah menyayangi semua manusia, tanpa memandang agama, keyakinan, jenis kelamin, dan warna kulit. Sehingga harkat dan martabat manusia sebagai mahluk ciptaan Tuhan dapat dipelihara dengan baik. ${ }^{18}$ Dan dalam Undang-undang Dasar 1945 pasal 29 ayat 1 dan 2 tentang agama tersebut:

a. Negara berdasarkan atas Ketuhanan Yang Maha Esa

b. Negara menjamin kemerdekaan tiap-tiap penduduk untuk memeluk agamanya masing-masing dan untuk beribadat menurut aagama dan kepercayaannya itu. ${ }^{19}$

Selain itu juga, dalam penjelasan tas Bab II angka I Pedoman Penghayatan dan Pengamalan Pancasila: ketetapan MPR No. II/MPR/1978 tertanggal 2 Maret 1978 menyebutkan bahwa "Kebebasan beragama adalah merupakan salah satu hak yang paling azasi manusia, karena kebebasan beragama itu langsung bersumber kepada martabat manusia sebagai mahluk ciptaan Tuhan. Hak kebebasan beragama bukan pemberian negara atau bukan pemebrian golongan". ${ }^{20}$

Dalam Undang-undang dasar mapun peraturan perundang-undangan tersebut diatas dengan jelas menyebutkan bahwa ada kemerdekaan individu tentang memeluk agama yang diyakini. Artinya kebebasan individu dilindungi oleh negara. Dan hal itu merupakan sebuah konskwensi dari adanya jaminan tersebut, sehingga setiap orang wajib menghormati kebebasan beragama orang lain. Dan disisi lain negara bertanggung jawab

${ }^{18}$ Anwar Harjono, Perjalanan Politik Bangsa: Menoleh Kebelakang Menatap Masa Depan, (Jakarta: Gema Insani Press, 1997), hlm. 147.

${ }^{19}$ Undang-undang Dasar 1945 Pasal 29 ayat 1 dan 2

${ }^{20}$ Kompolasi Peraturan Perundang-undangan Kerukunan Hidup Umat Beragama, cet. Ke-7, (Jakarta: Departemen Agama RI. 2003), hlm. 7. 
untuk melindungi, memajukan, dan memenuhi kebebasan beragama sebagai hak asasi manusia (Pasal $28 \mathrm{~J}$ Ayat [1] dan [4] UUD 1945). ${ }^{21}$

\section{Fatwa MUI dan Komnas HAM Terhadap Jamaat Ahmadiyah}

MUI mengeluarkan fatwanya dalam MUNAS VII tahun 2005 tentang Ahmadiyah sebagai berikut:

1. Bahwa sampai saat ini, aliran Ahmadiyah terus berupaya untuk mengembangkan pahamnya di Indonesia. Walaupun sudah ada fatwa MUI dan telah dilarang keberadaannya.

2. Bahwa upaya pengembangan faham Ahmadiyah tersebut telah menimbulkan keresahan masyarakat

3. Bahwa aliran Ahmadiyah telah berada diluar jalur Islam, sesat dan menyesatkan, serta orang Islam yang mengikutinya adalah murtad (keluar dari Islam)

4. Bagi mereka yang terlanjur mengikuti Ahmadiyah supaya segera kembali kepada ajaran Islam yang khaq (al-ruju' ila alhaqq) yang sejalan dengan al-Qur'an dan al-Hadis

5. Bahwa dengan jelas bahwa al-Qur'an dan Sunnah Rasulullah secara qoth'I telah menetapkan bahwa kenabian dan kerosulan telah berakhir (tertutup) setelah kerosulan Nabi Muhammad SAW. Maka siapa saja yang mengaku sebagai nabi setelah Nabi Muhammad berarti ia telah keluar dari Islam. Dan bahwa aqidah ini (tidak ada Nabi setelah nabi Muhammad SAW) adalah keyakinan yang fundamental dan mendasar, yang tidak menerima ta'wil dan takhsis apapun. Karena ia telah ditegaskan dengan jelas dalam al-Qur'a $>$ n

${ }^{21}$ Salahudin Wahid, "Perlindungan Hak Atas Kebebasan Beragama", makalah disampaikan pada workshob A National Workshob Of Freedom on Belief as A Human Rights in Indonesia. Diselenggarakan oleh Centre for Religion and Socio-Cultural Diversity (CRSD) UIN Sunan Kalijaga, Yogyakarta 10-12 Desember 2008, hlm. 2. 
dan hadis-hadis mutawatir yang qath'I serta telah menjadi ijma para ulama.

6. Bahwa Mirza Ghulam Ahmad telah nyata-nyata mengaku dirinya sebagai nabi maka ia telah keluar dari Islam. Adapun adanya ta'wil dan tafsir akan kenabiannya sebagai "nabi dzilyi", "buruzy" nabi ghaairu tasyri" atau "nabi ummati" hukumnya adalah sama. Hal ini dikarenakan aqidah tentang khataman nabiyyin, adalah aqidah qath'iyyah yang tidak dapat dita'wil ataupun di takhsi>s. tidak ada satupun dalil yang dapat dijadikan sandaran mereka. Sebagaimana sehabat nabi memerangi Musailimah al-Kadza>b, Aswad al-Unsa dan Thalailah bin Khuwailid yang mengaku nabi dengan cara mena'wil ma'na nubuwwah dan risalah.

7. Bahwa beriman dengan orang yang mengaku dirinya nabi hukumnya sama dengan yang diimaninya.

8. Bahwa pengakuan Mirza Ghulam Ahmad sebagai al-Mahdi, dan al-Masih yang dijadikan menjelang hari kiamat, sebagaimana diakui Qidiyan mapun Lahore adalah kebohongan dan pembohongan terhadap al-Qur'a $>n$, Sunnah Mutawatir dan Ijma.

Selain itu, seperti telah dijelaskan, bahwa mekipun MUNAS MUI VII menetapkan aliran Ahmadiyah telah keluar dari Islam, sesat dan menyesatkan, namun MUI tetap mengajak dan menyerukan para pengikut Ahmadiyah untuk kembali kepada ajaran Islam yang haq sejalan dengan al-Qur'a $>n$ dan Hadis. MUI juga meminta pemerintah untuk melarang penyebaran faham Ahmadiyah dan membekukan organisasinya serta menutup semua kegiatannya. Dengan kata lain eksekusi dilakukan oleh pemerintah selaku ulil amri. MUI tidak membenarkan segala bentuk tindakan yang merugikan pihak lain, apalagi tindakan anarkis terhadap pihak-pihak, hal-hal atau kegiatan yang tidak sejalan dengan fatwa MUI ini. 
Fatwa yang dikeluarkan oleh MUI tentang aliran Ahmadiyah, mendapat tanggapan dari berbagai kalangan, ada pro dan kontra. Pendapat yang pro, mendasarkan pendapatnya kepada pada keutuham Islam dan kemurnian ajaran Islam. Dan sebagai umat, Islam wajib untuk terus menjaganya. Sedangkan yang kontra, yaitu dengan melihat kekerasan yang terjadi kepada warga Ahmadiyah, baik fisik mapun psikis dengan mendasarkan pada Undang-undang kebebasan beragama dan berkeyakinan.

Padangan yang kontra terhadap pandangan atau keberadaan Ahmadiyah adalah Komisi Nasional HAM (Komnas HAM). Komnas HAM, memberikan pernyataan sehubungan dengan adanya Surat Keputusan Bersama (SKB) tiga menteri yaitu: menteri Agama, menteri Dalam Negeri, dan Jaksa Agung tentang peringatan dan perintah kepada penganut, anggota Jamaat Ahmadiyah Indonesia dan warga masyarakat, sebagai berikut:

1. Undang-undang dasar 1945 memberikan adanya jaminan bagi setiap orang bebas untuk memeluk agamanya masingmasing dan peribadatan menurut agama dan keprcayaannya $\mathrm{itu}^{22}$ UUD 1945 juga menegaskan, bahwa hak untuk memeluk agama dan beribadat sesuai dengan keyakinannya adalah merupakan hak yang tidak dapat dikurangi dalam keadaan apapun dan oleh siapapun (non derogable).

2. Bahwa negara, terutama pemerintah mempunyai kewajiban sebagaimana dimandatkan di dalam konstitusi untuk memberikan perlindungan, pemajuan, penegakan, dan pemenuhan HAM. Dalam kaitannya dengan kewajiban untuk memberikan perlindungan, negara seharusnya memberikan kemudahan dan perlindungan bagi warga negara menjalankan agama dan keyakinannya. Bukan sebaliknya membatasi hakhak warga negara menjalankan ajaran agamanya.

\footnotetext{
${ }^{22}$ Pasal 29 Ayat [2] UUD 1945
} 
3. Bahwa sesuai dengan ketentuan pasal 73 Undang-undang Nomor 39 tahun 1999 tentang Hak Asasi Manusia, pembatasan hak dan kebebasan hanya dapat dibatasi oleh dan berdasarkan Undang-undang. Berdasarkan hal tersebut, maka pembatasan dan pelanggaran bagi Jemaat Ahmadiyah melalui Keputusan Bersama ini tidak sejalan dengan amanah Pasal 73 tersebut.

4. Berdasarkan pada kewajiban konstitusional negara tersebut dan kewajiban internasional, kami berpandangan Keputusan Bersama menteri Agama, Jaksa Agung dan Menteri Dalam Negeri dapat mengurangi secara serius ketaatan Negara ini terhadap kewajiban dasarnya, yaitu menjaga konstitusi dan kewajiban Internasional hak asasi manusia.

Secara konseptual, jaminan kebebasan beragama di Indonesia sangat jelas dan tegas sebagaimana dinyatakan dalam UUD 1945 pasal 29 mengenai agama. Pernyataan jaminan kebebasan beragama dalam UUD 1945 tersebut pada prinsipnya sejalan dengan isi Deklarasi Universal PBB $1948 .^{23}$ Untuk menunjang pelaksanaan pasal 29 (2) UUD 1945 pemerintah kemudian mengeluarkan UU. No. 1/PNPS/1965 tentang pencegahan penyalah gunaan dan atau penodaan agama. Undang-undang Ini selanjutnya dikukuhkan oleh UU. No. 5 tahun 1965.

Fatwa MUI tentang aliran Ahmadiyah tersebut memunculkan kontrafersi dalam masyarakat termasuk dikalangan umat Islam itu sendiri. Sebagian masyarakat sangat memahami fatwa MUI tersebut, bahkan menganggab sebagai

${ }^{23}$ Deklarasi Universal PBB 1948 tentang HAM Pasal 18 "Setiap orang berhak atas kemerdekaan berpikir, berkeyakinan dan beragama; hak ini mencakup kebebasan untuk berganti agama atau kepercayaan, dan kebebasan untuk menjalankan agama atau kepercayaannya dalam kegiatan pengajaran, peribadatan, pemujaan dan ketaatan, baik sendiri maupun bersama-sama dengan oranglain, di muka umum maupun secara pribadi”.

Fikri, Vol. 3, No. 1, Juni 2018 
bagian dari menunaikan tugas kewajiban lembaga itu dalam memberikan tuntunan dan bimbingan kepada umat Islam maupun masyarakat. Demikian pula dengan desakan MUI agar pemerintah RI bersikap tegas terhadap aliran Ahmadiyah, hal itu dianggap sebagai kewajaran, karena salah satu kewajiban MUI adalah memberikan nasehat kepada pihak-pihak yang memerlukan, termasuk pemerintah MUI.

Sementara itu dengan sudut pandang yang berbeda sebagian orang mengaggap MUI telah melampaui batas kewenangannya dengan menjatuhkan vonis sesat kepada suatu aliran keagamaan, padahal kewenangan itu, menurut mereka adalah milik Allah. Sementara alasan lain yang dikemukakan adalah bahwa tindakan yang akan diambil pemerintah, apabila memenuhi seruan MUI untuk menindak aliran Ahmadiyah merupakan pelanggaran serius terhadap hak kebebasan beragama dan berkeyakinan sebagai bagian dari Hak Asasi Manusia (HAM). Bahkan fatwa diatas, telah dituduh sebagai pemicu dari berbagai tindak kekerasan sebagai umat Islam terhadap warga Ahmadiyah. ${ }^{24}$

\section{Pandangan MUI dan Komnas HAM Terhadap Kebebasan Beragama dan Berkeyakinan}

Islam dan negara Indonesia mepunyai hubungan timbal balik yang saling memerlukan. Islam memerlukan negara Indonesia sebagai wahana mewujudkan nilai-nilai universal Islam sebagai landasan bagi pembangunan masyarakat yang maju dan berakhlak. ${ }^{25}$ Oleh karena itu, keberadaan organisasi

24 A. Malik Madany, Memahami Fatwa Mejelis Ulama Indonesia tentang Ahmadiyah, disampaikan dalam serasehan "Aliran Sesat dan Ukhuwah Ummat" yang diselenggarakan oleh MUI Propinsi DIY, Sabtu, 19 Juli 2008 di Asrama Haji Yogyakarta.

${ }^{25}$ Habib Shulton Asnawi, "Sanksi Perpajakan dan Pengadilan Pajak Di Indonesia: Upaya Optimalkan Perolehan Pajak Kaitannya dengan 
para ulama, zuama dan cendikiawan muslim adalah suatu konsekwensi logis dan prasyarat bagi perkembangnya hubungan untuk kemashlahatan seluruh rakyat Indonesia. ${ }^{26}$

Tanpa komitmen terhadap kebenaran, hidup menjadi tidak bermakna. Karenanya, agama tanpa klaim kebenaran (truth claim), akan kehilangan dimensi eksistensinya, yaitu hidup dijalan yang diridhoi Tuhan. ${ }^{27}$ Menurut Whitehead, truth claim adalah penting baik dalam agama untuk membungkus kalim kebenaran. Dogma dalam agama berfungsi untuk memformulasikan kebenaran pengalaman rasional. Maka dari itu dianggap wajar ketika MUI sebagai lembaga yang bertugas memberikan nasihat dalam hukum Islam mengeluarkan fatwa sesat terhadap aliran Ahmadiyah karena dirasa telah meresahkan fatwa sesat terhadap aliran ahmadiyah, karena dirasa telah meresahkan sebagai masyarakat Muslim Indonesia. Dan kekerasan yang terjadi terlepas dari fatwa MUI, karena MUI sendiri telah menghimbau agar masyarakat tidak berbuat anarkis yang mengakibatkan jatuhnya korban.

Sedangkan Komnas HAM sebagai lembagai yang memperjuangkan Hak Asasi Manusia, melihat kenyataan yang ada yaitu kekerasan baik psikis maupun psikologis merasa bertanggung jawab untuk menyelesaikan masalah yang sedang di hadapi warga negara Indonesia. Yang pada akhirnya menyerempet pada permasalahan kebebasan beragama dan berkeyakinan. Dalam hal ini Komnas HAM seharusnya hanya

Pembangunan Nasional," Adzkiya Jurnal Hukum dan Ekonomi Syari'ah, 2, 05-No.2 (2017).

26 Ahmad Subakir, Kontraversi Fatwa MUI tentang Ahmadiyah, "Respon Tokohh Islam Atas Fatwa MUI Tentang Gerakan Ahmadiyah Indonesia”, Surabaya, eLKAF, 2007), hlm. 47-48.

27 Habib Shulton Asnawi, "Politik Hukum Kesetaraan Kaum Perempuan Dalam Organisasi Masyarakat Islam Di Indonesia," Musãwa Jurnal Studi Gender Dan Islam 11, no. 1 (29 Januari 2012): 67-84, https://doi.org/10.14421/musawa.2012.111.67-84. 
masuk kedalam pembuktian adanya tindak kekerasan atau benturan antara satu pihak dengan pihak lain dan bukan kemasalah teologis.

MUI dan Komnas HAM adalah dua lembaga yang independen dan keputusan-keputusannya sama-sama tidak mengikat. Kedua lembaga ini sama-sama mempunyai bertanggung jawab untuk memajukan negara Indonesia. Pandangan MUI terhadap kebebasan berpendapat atau berkeyakinan adalah sah-sah saja dalam arti dobolehkan. Yang dimaksud disini adalah kebebasan beragama. MUI lebih menitikberatkan pada prinsip keyakinan. Sedangkan Komnas HAM lebih menitik beratkan pada aspek logika, dengan kepentingan-kepentingan di dalamnya. Dalam agama Islam, Islam sangat menghormati keyakinan orang lain, namun ketika agama Islam diselewengkan dalam hal akidah, maka MUI berkewajiban untuk meluruskan akidah tersebut, dalam kaitannya dengan masalah fiqih dan firu' boleh saja berbeda, karena Islam sangat menghormati atau menghargai perbedaan. ${ }^{28}$

\section{E. Pandangan MUI dan Komnas HAM Terhadap Jamaat Ahmadiyah Indonesia}

MUI mendasarkan fatwanya tentang aliran Ahmadiyah berdasarkan al-Qur'a $>n$, al-Hadis, Ijma' para ulama sedunia. Selain itu MUI juga mendasarkan pada UU/PNPS No. 1 tahun 1965 Pasal 1 tentang Penodaan Agama yang berbunyi "Setiap orang dilarang dengan sengaja dimuka umum menceritakan, menganjurkan atau mengusahakan dukungan umum, untuk melakukan penafsiran tentang sesuatu agama yang dianut di Indoensia atau melakukan kegiatan-kegiatan keagamaan yang

${ }^{28}$ Dalam kasus Ahmadiyah, yang terjadi adalah penyelewengan dalam hal akidah karena mengingkari yaitu Nabi Muhammad SAW. Maka MUI memutuskan bahwa Ahmadiyah adalah sesat dan menyesatkan karena MUI mempunyai aturan yang baku dan prinsip sesuai dengan hukum Islam. 
menyerupai kegiatan-kegiatan keagamaan dari agama itu, penafsiran dan kegiatan mana menyimpang dari pokok-pokok ajaran agama itu. ${ }^{29}$

Sedangkan kaitannya dengan kebebasan beragama dan berkeyakinan seperti yang diusung oleh Komnas HAM tentang aliran Ahmadiyah, menurut MUI bukanlah proporsinya masuk keranah kebebasan beragama seperti yang dituangkan dalam alQur'an, UUD 1945 dan UU HAM. Menurut Ahmad Muchsin Kamaludiningrat, masalah kebebasan beragama, Islam telah memiliki pedoman yang samat jelas sebagaimana tercantum dalam di dalam al-Qur'a $>$ n.

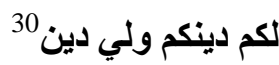

Islam tidak menganggu agama orang lain, bahkan Islam menghormati dan mengakui eksistensi agama lain. Tugas Islam adalah melakukan dak'ah atau ajakan kepada Islam sebagai agama yang diakui disisi Allah. Lebih lanjut Ahmad Muchsin mengatakan bahwa HAM yang mengusung paham kebebasan dan hanya mengandalkan pada pekirin dan nafsu manusia, tidaklah sesuai dengan ajaran Islam. HAM yang memiliki sumber nilai mutlak dari agama, yaitu ajaran Tuhan (sebagai pencipta manusia) menjadikan paham tersebut identik dengan sekuler yang menganggap bahwa kehidupan manusia ini hanya ada di dunia ini saja.

Kalau pemahaman dan penerimaan HAM seperti itu sebenarnya bertentangan dan mengancam Pancasila dan UUD 1945, sebagai Pancasila jelas mendasarkan ketuhanan Yang Maha Esa sebagai sila pertama, dan pengakuan bahwa adanya kemerdekaan Indonesia ini adalah "Atas berkat dan Rahmat Tuhan Yang Maha Kuasa”.

${ }^{29}$ Lembaran Negara Republik Indonesia No. 3, 1965 Penyalahgunaan dan/atau penodaan Agama, (Jakarta: tnp. 1965),hlm. 1.

${ }^{30}$ Q. S. al-Kafirun [109]: 6. 
Aliran-aliran yang ada di Indonesia yang dinyatakan sesat oleh MUI sangat banyak dan bertindak kepada Islam. Munculnya aliran sesat tersebut adalah karena adanya ketidak puasan umat kepada para pemimpin umat atau ulama. Ketidakpuasan tersebut juga terhadap keadaan umat Islam Indonesia yang tidak mencerminkan ajaran al-Qur'a $>n$ itu, para pencetus aliran "sesat" tersebut pada umumnya tetap mengaku berpedoman kepada al-Qur'a>n dengan tafsir dan ta'wil yang mereka fahami secara literal, tanpa memegangi aqidah tafsir dan ta'wil yang dipegangi para ulama, dan tidak mengakui terhadap hadis dan sunnah. ${ }^{31}$

Oleh karena itu munculnya aliran-aliran ini adalah sebagai solusi alternative untuk menghilangkan atau mengurangi keresahan dan kekecewaan tersebut. Ada yang radikal berpendapat bahwa munculnya aliran sesat ini disuga sebagai permainan dan skenario pihak tertentu untuk menghancurkan NKRI dan agama serta umat Islam.

Perbedaan pendapat adalah hal yang wajar, bahkan Nabi Muhammad SAW mengisyaratkan bahwa "perbedaan pendapat diantara umatku adalah rahmat" tetapi perbedaan yang diizinkan adalah perbedaan dibidang furu'/khilafiyah bukan dalam bidang pokok (akidah). MUI telah menetapkan pedoman identitas aliran sesat dalam rakernas MUI tahu 2007 dalam pedoman tersebut telah ditetapkan ada kreteria suatu faham atau aliran dinyatakan sesat apabila memenuhi salah satu dari kreteria berikut:

1. Mengingkari dari salah satu dari rukun iman yang 6 (enam) yakni beriman kepada Allah, kepana Malaikat, kepad Kitab-kitab-Nya, kepada Rasul-rasul-Nya, kepada Hari Akhirat, kepada Qodlo dan Qodar dan rukun Islam

31 Sunyoto Usman, disamapaikan pada seminar nasioanl tentang kebebasan berkeyakinan, aliran sesat dan jaminan konstitusi (Urgensi pengaturan kebebasan berkeyakinan, diselenggarakan oleh mahasiswa Fakultas Hukum UGM, Yogyakarta 14 Mei 2008. 
yang 5 (lima) yakni mengucapkan dua kalimat syahadat, mendirikan shalat, mengeluarkan Zakat, berpuasa pada bulan ramadhan, menunaikan ibadah haji.

2. Meyakini atau mengikuti akidah yang tidak sesuai dengan dalil syara' (al-Qur'a $>n$ dan al-Hadis)

3. Meyakini turunnya wahyu setelah al-Qur'a $>n$

4. Mengingkari otentitas dan atau kebenaran isi al-Qur'a $>n$

5. Melakukan penafsiran al-Qur'a $>n$ yang tidak berdasarkan kaidah-kaidah tafsir

6. Mengingkari kedudukan hadis Nabi sebagai sumber ajaran rasul

7. Menghina, melecehkan dan atau merendahkan para Nabi dan Rosul.

8. Mengingkari Nabi Muhammad SAW sebagai Nabi dan Rosul terahir

9. Merubah, menambah dan atau mengurangi pokok-pokok ibadah yang telah ditetapkan oleh syari'at, seperti haji, tidak ke Baitullah, shalat fardlu 5 (lima) waktu tidak wajib

10. Mengkafirkan sesame muslim tanpa ada dalil syar'I seperti mengkafirkan muslim hanya karena bukan kelompoknya.

Menurut Syafi'I Anwar, kalau melihat sejarah tokoh Ahmadiyah banyak melahirkan karya-karya bagi umat Islam. Salah satunya The Holy Qur'a>n: Arabic Text, Translation and Comentary, karya Ahmad Yusuf Ali yang telah banyak diterjemahkan keberbagai bahasa di dunia. Dengan adanya kekerasan yang dialami oleh Ahmadiyah, maka sekarang yang lebih penting adalah peran negara dalam memberikan perlindungan terhadap kebebasan beragama. Negara harus berperan secara maksimal dalam melindungi hak-hak warga negara, dan mampu bertindak secara adil dan netral untuk 
melindungi hak setiap warga negera tanpa membedakan suku, agama, ras, dan sebagainya.

Disisi lain Komnas HAM sebagai lemabaga yang bertugas untuk menegakkan HAM dalam kasus Ahmadiyah, dikarenakan banyaknya kekerasan yang terjadi pada warga Ahmadiyah disebabkan karena adanya keyakinan. Dalam hal ini Komnas HAM mengeluarkan pernyataan sehubungan adanya kasus Ahmadiyah. Yaitu dengan mendasarkan pada UUD 1945 yang memberikan jaminan bagi setiap orang bebes untuk memeluk agamanya masing-masing dan beribadat menurut agama dan kepercayaannya itu, dan hak ini tidak dapat dikurangi dalam keadaan apapun dan oleh siapapu. Negara juga berkewajiban melindungi rakyatnya dalam beragama dan berkeyakinan.'

Batasan-batasan dalam HAM seperti yang tertuang pada UU No. 39 tahun 1999 tentang Hak Asasi Manusia. Yang berbunyi:

"Hak dan kebebasan yang diatur dalam Undang-undang ini hanya dapat dibatasi oleh dan berdasarkan Undang-undang, semata-mata untuk menjamin pengakuan dan kehormatan terhadap hak asasi manusia serta kebebasan dasar orang lain, kesusilaan, ketertiban umum dan kepentingan bangsa",32

Dalam kaidah Fiqih juga disebutkan:

$$
\text { "حرية المرعى محدودة بحرية غيره }
$$

Artinya bahwa hak seseorang dibatasi oleh adanya kebebasan orang lain. ${ }^{33}$

Dari sini kita dapat pahami bahwa selama kebebasan itu tidak mengganggu kebebasan orang lain maka itu sah-sah saja, namun ketika ada hak orang lain terlanggar maka hak seseorang

${ }^{32}$ Lihat Pasal 73 UU. No. 39 tahun 1999 tentang Hak Asasi Manusia.

33 Salahudin Hamid, Hak Asasi Manusia dalam Perspektif Islam, (Jakarta: Amisco, Cet. 1, 2000), hlm. 11. 
tidak secara mutlak. ${ }^{34}$ Pasal 73 UU. No. 39 tahun 1999 dibatasi oleh Pasal 156a KUHP bab V tentang kejahatan terhadap ketertiban umum yang isinya "dipidanan dengan pidana penjara selama-lamanya 5 tahun, barang siapa dengan sengaja di muka umum mengeluarkan perasaan atau melakukan perbuatan”.

a. Yang pada pokoknya bersifat permusuhan, penyalahgunaan atau penodaan terhadap suatu agama yang dianut di Indonesia

b. Dengan maksud agar orang lain tidak menganut agama apapun juga yang bersendikan ketuhanan Yang Maha Esa.

Dari sini maka dapat kita simpulkan bahwa kebebasan itu juga ada batasan-batasannya, dan tidak secara mutlak kebebasan digaungkan. Jika kebebasan itu menimbulkan keresahan warga lain atau masyarakat maka kebebasan itu tidak mutlak. HAM yang digunakan di Indonesia tidak harus sama dengan HAM yang digunakan oleh negara lain. HAM yang digunakan di Indonesia sesuai dengan social, budaya, agama, ekonomi dan juga politik. Maka dari itu perlu adanya dialog terus-menerus sebagai upaya menghindari terjadinya kesalah fahaman dan kekerasan pada warga negara.

Dari ini semua paparan penyusun di atas terdapat beberapa hal yang perlu dilakukan oleh masyarakat Indonesia agar terciptanya suatu keadaan yang aman dan tentram antara sesame manusia, yaitu perlu adanya dialog antara MUI, HAM, Ahmadiyah dan juga pemerintah untuk menemukan solusi yang baik untuk semua pihak, karena pennyususn berkesimpulan bahwa danya perbedaan penafsiran kata Nabi itu sendiri, juga tentang wahyu dan ilham, Ahmadiyah tidak membedakan

34 Habib Shulton Asnawi, "HAM dalam Ruang Domestik: Studi terhadap UU. No. 23 Tahun 2004 Tentang PKDRT," Al-Mawarid Jurnal Hukum Islam 11, no. 2 (2011): 195-210, http://www.jurnal.uii.ac.id/index.php/JHI/article/view/2861. 
keduanya, sedangkan umat Islam di Indonesia membedakannya. Maka dari itu perlu adanya komunikasi yang lebih baik untuk mendapatkan pemecahan permasalahan bagi masyarakat maupun bagi negra Indonesia.

\section{F. Kesimpulan}

Dari sini dapat diambil beberapa kesimpulan: Potret kebebasan beragama di Indonesia sesungguhnya sudah brkembang sejak bangsa ini akan diproklamirkan tahun 1945 silam, bahkan jauh sebelum itu. Melalui Badan Penyelidik Usaha-usaha Persiapan Kemerdakan Indonesia (BPUPKI), wacana ini hangat diperdebatkan founding father khususnya dalam perumusan pasal 29 UUD 1945. Kebebasan beragama (bebas berkeyakinan) merupakan hak setiap manausia dan pada dasarnya HAM tidak dapat dibatasi atau dilanggar. Akan tetapi, dalam kasus-kasus tertentu HAM dapat dibatasi asalkan dapat diatur dalam Undang-undang dengan bertujuan semata-mata hanya untuk menjamin agar HAM orang lain dihormati dan tidak dilanggar. Di Indonesia dalam pelaksanaannya HAM tidak boleh merugikan sesama dalam masyarakat.

Oleh karena itu, batas hak-hak pribadi adalah dia mana hak masyarakat terancam dalam pembahagiakan para warganya. Sehingga kemudian HAM dalam pandangan Islam terbatas pada hak orang lain, sebagaimana kaidah mengatakan:

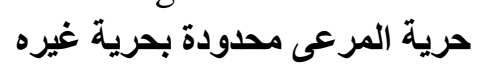

Artinya "bahwa hak seseorang di batasi oleh adanya kebebasan orang lain". Manusia adalah sentral utama pembicaraan berbagai hak, karena pada prinsipnya hak-hak itu dibatasi untuk kepentingan masyarakat, maka pembatasn tersebut tidak lain hanyalah untuk kepentingan manusia itu sendiri yang menurut tabiatnya ia adalah makhluk social, yang mau tidak mau harus melakukan interaksi social dengan sesamanya. Dalam pendapatmya, MUI khususnya fatwa MUI tentang aliran 
Ahmadiyah, menyakana bahwa tidak ada Nabi setelah Nabi Muhammad SAW. Dan baran siapa mengaku Nabi setelah Nabi Muhammad SAW, maupun para pengikutnya yang mengakuinya adalah sesat dan menyesatkan. Hal ini berdasarkan surat al-Ahzab 40, al-An'am ayat 153 dan surat al-Maidah ayat 105 yang menjelaskan bahwa tidak ada Nabi sesudah Nabi Muhammad SAW. Juga dalam Hadis Riwayat Bukhari dan alTarmidzi yeng menyebtkan bahwa tidak ada Nabi sesudah Nabi Muhammad SAW. Juga keputusan Ijma' para ulama sedunia yang diwakili oleh OKI. Seangkan Komnas HAM mendasarkan pada UUD 1945 dan UU HAM No. 39 tahun 1999 tentang Hak Asasi Manusia. Bahwa kebebasan beragama dan berkeyakinan adalah hak yang tidak bisa dicabut oleh apapun. Namun disini ada pasal 156a KHUP bab $\mathrm{V}$ tentang kejahatan terhadap ketrtiban umum.

Pendapat kedua lembaga ini bertolak belakang, namun pada kenyataannya mereka sama dalam visi dan misi yaitu terwujudnya masyarakat yang adil dan makmur. MUI lebih kepada untuk lebih memurnikan ajaran Islam agar tidak disalah gunakan oleh orang yang ingin menhancurkan Islam dari dalam maupun dari luar. Sedangkan komnas HAM lebih kepada sesi kemanusiaan dengan acuan logika yaitu banyaknya korban kekerasn-kekerasan yang terjadi akibat dari fatwa tersebut. MUI sendiri mnginginkan tidak terjadinya anarkhisme pada warga Ahmadiyah karena adanya pihak-pihak yang memprovokasi adanya tindak kekerasan tersebut. Kebebasan berkeyakinan menurut MUI sangat dihormati dalam arti kebebasan beragama, dan sah-sah saja. Kebebasan berpendapat yang diperbolehkan dalam Islam adalah dalam hal fiqih bukan akidah. Sedangkan Komnas HAM kebebasan berkeyakinan adalah secara mutlak dan dalam arti yang seluas-luasnya, yaitu hak untuk mempunyai keyakinan sendiri tanpa ada batasan. 


\section{Daftar Pustaka}

\section{Jurnal Ilmiah:}

Asnawi, Habib Shulton. "Dasar Hukum Hakim Mahkamah Konstitusi Dalam Memutuskan Perkara No.46/PUUVIII/2010 Tentang Status Hukum Anak Di Luar Nikah (Perspektif Hukum Islam Dan Hak Asasi Manusia)." FIKRI: Jurnal Kajian Agama, Sosial Dan Budaya 1, no. 1 (3 Maret 2016): 45-78. http://journal.iaimnumetrolampung.ac.id/index.php/jf/art icle/view/7.

. "HAM dalam Ruang Domestik: Studi terhadap UU. No. 23 Tahun 2004 Tentang PKDRT." Al-Mawarid Jurnal Hukum Islam 11, no. 2 (2011): 195-210. http://www.jurnal.uii.ac.id/index.php/JHI/article/view/28 61.

. "Membongkar Paradigma Positivisme Hukum dalam Pemberantasan Korupsi di Indonesia: Pemenuhan Hak Asasi Manusia dalam Negara Hukum." SUPREMASI HUKUM: Jurnal Ilmu Hukum, 2013. http://www.aifisdigilib.org/uploads/1/3/4/6/13465004/02._ham_islam_da n_barat_habib_shulton_asnawi.pdf.

"Politik Hukum Kesetaraan Kaum Perempuan Dalam Organisasi Masyarakat Islam Di Indonesia." Musãwa Jurnal Studi Gender Dan Islam 11, no. 1 (29 Januari 2012): 67-84.

https://doi.org/10.14421/musawa.2012.111.67-84.

. "Politik Hukum Putusan MK Nomor 36/PUU-X/2012 dalam Upaya Mengembalikan Kedaulatan Negara dan Perlindungan HAM." Jurnal Konstitusi 13, no. 2 (27 Agustus 2016):

299-320.

http://ejournal.mahkamahkonstitusi.go.id/index.php/jk/ar ticle/view/337.

- "Sanksi Perpajakan dan Pengadilan Pajak Di Indonesia: Upaya Optimalkan Perolehan Pajak Kaitannya dengan Pembangunan Nasional." Adzkiya Jurnal Hukum dan Ekonomi Syari'ah, 2, 05-No.2 (2017). 


\section{Buku:}

A. Malik Madany, Memahami Fatwa Mejelis Ulama Indonesia tentang Ahmadiyah, disampaikan dalam serasehan "Aliran Sesat dan Ukhuwah Ummat" yang diselenggarakan oleh MUI Propinsi DIY, Sabtu, 19 Juli 2008 di Asrama Haji Yogyakarta.

Ahmad Subakir, Kontraversi Fatwa MUI tentang Ahmadiyah, "Respon Tokohh Islam Atas Fatwa MUI Tentang Gerakan Ahmadiyah Indonesia”, Surabaya, eLKAF, 2007.

Ali Syafie, Konsep-Konsep Istihsan, Istislah dan Maslahah alAmmah, dalam Budy Munawar Rochman (Ed.), Kontekstualisasi Doktrin dalam Syari'ah, Jakarta: Paramadina, 1995

Anwar Harjono, Perjalanan Politik Bangsa: Menoleh Kebelakang Menatap Masa Depan, (Jakarta: Gema Insani Press, 1997), hlm. 147.

Iskandar Zulkarnain, Gerakan Ahmadiyah di Indonesia, Jakarta: LKis, 2005

J.C.T. Somorangkir, Hukum dan Konstitusi Indonesia, (Jakarta: PT. Gunung Agung, 1983

Kompolasi Peraturan Perundang-undangan Kerukunan Hidup Umat Beragama, cet. Ke-7, Jakarta: Departemen Agama RI. 2003)

Kuntowijoyo, Identitas Politik Islam, (Bandung: Mizan, 1997), hlm. 169. Lihat juga, Hamka Kaq, Islam Rahmah Untuk Bangsa, (Jakarta: RMBOOKS, 2009

Lembaran Negara Republik Indonesia No. 3, 1965

Penyalahgunaan dan/atau penodaan Agama, Jakarta: tnp. 1965.

Moh. Kusnardi dan Harmaily Ibrahim, Pengantar Hukum Tata Negara Indonesia, Jakarta: Pusat Studi HTN FH-UI, 1981

Munawir Sadzali, Islam dan Tata Negara, Ajaran Sejarah dan Pemikiran, Jakarta: UI Press, 1995

Salahudin Wahid, "Perlindungan Hak Atas Kebebasan Beragama", makalah disampaikan pada workshob A 
National Workshob Of Freedom on Belief as A Human Rights in Indonesia. Diselenggarakan oleh Centre for Religion and Socio-Cultural Diversity (CRSD) UIN Sunan Kalijaga, Yogyakarta 10-12 Desember 2008.

Sekretariat Jendral, MPR RI, Risalah Rapat-rapat Panitia Ad Hac BP MPR, Buku Kedua Jilid 3C Jakarta,

Siti Musdah Mulia, Potret Kebebasan dan Berkeyakinan di Era Revormasi, Disajikan pada Lokarya Komnas HAM "Penegakan HAM dalam 10 Tahun Revormasi, di Hotel Borobudur Jakarta, 8-11 Juli 2008.

Undang-undang Dasar 1945 Pasal 29 ayat 1 dan 2

Yusuf Qaradhawi, Fatwa; Antara Ketelitian dan Kecerobohan, alih bahasa As'ad Yasin, Jakarta: Gema Insani Press, 1997.

Yusuf Qardlowi, Sistem Masyarakat dalam al-Qur'an dan Sunnah, trj. Abdus Salam Masykur, Solo: Citra Islami Press, 1997 